JELTL (Journal of English Language Teaching and Linguistics) e-ISSN: 2502-6062, p-ISSN: 2503-1848

2019, Vol. 4(3)

www.jeltl.org

\title{
Indonesian-English Code-Switching in Gogirl! Magazine: Types and Features
}

\author{
Agatha Elma Febiyaska \\ Sanata Dharma University \\ agathaelma@gmail.com \\ Priyatno Ardi \\ Sanata Dharma University \\ priyatnoardi@usd.ac.id
}

\begin{abstract}
The present study investigates the types and features of Indonesian-English code switching in GoGirl! Magazine of March to May 2016 editions. Content analysis was employed in this study. The results of the analysis revealed that 1.355 cases of Indonesian-English code switching appeared in the magazines. The types of code-switching included alternation, insertion, and congruent lexicalization. The features of code switching in the magazines were several constituents, non-nested $a b$ a, length and complexity, discourse particles and adverbs, peripherality, single constituent, nested $a b$ a, content words, linear and structural equivalence, multi-constituent code-mixing, non-constituent mixing, and triggering. The researchers concluded that the mostly used type was alternation and non-nested $a b$ is the mostly used feature in GoGirl! Magazine.
\end{abstract}

Keywords: code switching, features of code switching, magazine, types of code switching

\section{INTRODUCTION}

Code-switching is a linguistic phenomenon that occurs in a multilingual country like Indonesia, which has a national language and a number of regional languages. The switch between Indonesian as the national language and regional languages or vice versa is often 


\section{Agatha Elma Febiyaska \& Priyatno Ardi}

heard in daily discourses (Yusuf, Fata, \& Chyntia, 2018). Nowadays, the presence of English as a foreign language taught in schools shapes the occurrence of Indonesian-English codeswitching phenomena in Indonesia. The mixture between English and Indonesian are often found in several genres, such as films, songs, newspapers, and novels (Adityanto, 2012; Martin-Anatias, 2019; Martin-Anatias, 2018; Martin-Anatias, 2018b; Rusli et al., 2018; Yusuf et al., 2018). As English is an international language, the mixed use of Indonesian and English in the texts shows that Indonesian people "live in both local and global worlds" (Martin-Anatias, 2018a).

Code-switching is generally defined as the use of two or more languages in conversations or written texts produced by bilingual speakers or writers (Gardner-Chloros, 2009). Martin-Anatias (2018a; 2018b; 2019) illustrates the concept of code-switching in Indonesia by analogy with gado-gado and thus code-switching is called bahasa gado-gado. The phenomena of code-switching in Indonesia is worth examining because it can be seen as a reflection of social concepts and cognitive mechanisms that control language switching (Bullock \& Toribio, 2009). Moreover, the frequent switch of languages in a society can be interpreted as the acceptance towards the code-switching phenomenon itself. The other reason is that people can produce utterances in a language, then switch it into another language at a time while keeping functional and pragmatic clarity. In this regard, codeswitching allows bilinguals to be clearly understood when they switch languages (Altarriba \& Basnight-Brown, 2009).

Based on the modes of code-switching, there are two kinds of code-switching, namely spoken and written code-switching. According to Sebba, Mahootian, \& Jonsson (2012), written mixed-language is still under-researched and studies about written code-switching are not as many as spoken code-switching due to two reasons. First, since linguistics is normative, researchers tend to focus on the specific language they specialize in and they will find difficulties in dealing with texts that use different languages. Secondly, code-switching in written texts has less coherent framework providing "a context for discussing and analyzing the data," compared to code-switching in spoken forms. As a result, many of the studies are mostly descriptive, "or confine themselves to a comparison with spoken data."

However, a number of studies on code-switching in written texts have been previously conducted. First, Adityanto (2012) conducted a study on CS in Kompas and Republika newspapers. He found six major types of CS, namely diglossic CS, single word CS, phrase CS, clause CS, whole sentence CS, and integrated loanword CS. Das \& Gambäck (2013) investigated the characteristics of CS in social media and developed system to detect automatically the language boundaries. Then, Zhiganova (2016) investigated what were conveyed by socio-cultural English values and how native speakers recognized English elements inserted in an advertisement.

Another printed media that often use CS in writing is magazines, especially teenage magazines. Teenage magazines in Indonesia show up with a lot of CS per edition. The readers of the magazines are mostly high school students and university students, who are still learning English and getting fun way to learn it through popular magazines. When they read the change of language from Indonesian into English in some articles, they will get new knowledge about English. As a result, they will use those English expressions from the 
magazine in other contexts after they understand the meaning and the purpose of those expressions.

Accordingly, additional studies of CS in a written form need conducting, not only in newspapers, but also in teenage magazines that are close to students' life nowadays. In this research, the researchers choose GoGirl! Magazine because the magazine frequently uses CS between Indonesian and English in the main articles. Therefore, the researchers intend to study further about CS in GoGirl! Magazine. The researchers focus on the types and features of CS that appear in GoGirl! Magazine.

\section{LITERATURE REVIEW}

\subsection{The Nature of Code-Switching}

Code-switching and multilingual society cannot be separated because code-switching happens in multilingual societies that use more than one language in communication. Bullock \& Toribio (2009) argue that CS is a phenomenon where bilinguals exploit their ability in switching from one language to another, frequently in the same statement. Bilinguals can speak in one language to certain people or in certain places, then shift to another language in other domains. Meanwhile, Gardner-Chloros (2009) state that various combinations of two or more linguistic varieties, such as several languages and dialects, that happen in the same sentence in many bilingual communities and societies are known as code-switching.

\subsection{Types of Code-Switching}

McCormick (1994) divides CS types into six, namely diglossia, situational CS, metaphoric CS, conversational CS, single-word CS, and integrated loanwords. The first type, diglossia, is a feature of speech community, instead of individuals (Wardhaugh, 1992). When diglossic situation happens, people use two different languages called the $H$ (high) and L (low) codes. One of the two languages has greater prestige than the other (McCormick, 1994). The example is what happens in Paraguay, where its people use two languages, namely Spanish and Guaraní. The use of these languages is based on the norms in the community. Spanish is used as a formal language in official and institutional contexts. Meanwhile, the use of Guaraní is in informal context (Bullock \& Toribio, 2009).

The second type of CS is situational CS. This type of CS is used based on the situation that happens when nobody understands the topic discussed using a certain language. The speaker should switch the language into another language that is more understandable. For example, in a magazine, there is an English sentence that reports on a celebrity's latest activities. In the next sentence, the same topic is re-written using Bahasa Indonesia to make sure the readers understand the discussed topic.

The third type is metaphoric CS. In this type, the use of CS shows how a speaker tries to show a relationship that is built while talking to another speaker. The speaker may change the language from formal to informal ones. Besides, the change from professional language into personal language can also happen in this case. Those language changes show the relationship between the speakers. An example from Sebba et al. (2012) of metaphoric CS can be seen in the English sentence that uses a Spanish phrase: "And nobody chinga con mi familia without answering to me!" The Spanish phrase 'chinga con mi familia,' which means 


\section{Agatha Elma Febiyaska \& Priyatno Ardi}

'screws with my family,' is used to avoid people who do not speak Spanish understand the meaning of the whole expression.

The fourth type is conversational CS. Any language elements can be used in switching languages in this type. The speakers can put together a phrase, clause, or sentence of two different languages. Gardner-Chloros (2009) gives an example of conversational CS where two villagers in a social security office in the Norwegian village of Hemnesberget talk about business using Standard Norwegian. They switch the language to the local dialect when the topic is about family and village.

The fifth type is single-word CS. This CS occurs by borrowing one word from another language to be used in a whole sentence. For example, an English word is inserted in a chunk of a German sentence, "...und Erwin auch, see," which means, "and Erwin as well, you see." The English word 'see' is borrowed to be inserted in the German sentence (Auer, 1998).

The sixth type is integrated loanwords. This type is using the suffix or prefix of a language after a word of another language. In this case, the use of suffix or prefix of Bahasa Indonesia is put before or after an English word. It can be seen that in this type, the juxtaposition happens in morpheme level.

In addition, Muysken (2000) reveals that there are three types of CS, namely alternation, insertion, and congruent lexicalization. Firstly, alternation happens if there is congruence or similarity between the grammars of two switched languages. The example of alternation is in this French mixed Dutch sentence, "Je téléphone á Chantal he, meestal voor commieskes te doen en eten." In English, it means 'I call Chantal to go shopping and get food' (Bullock \& Toribio, 2009). The two languages have similar grammar so that some words in French can be inserted in the Dutch sentence.

Secondly, insertion occurs when some elements which are longer than a word is inserted in a sentence. The elements of Language $\mathrm{A}$ are inserted into a sentence with Language B grammar. For example, the Dutch prepositional phrase is inserted into a Moluccan Malay sentence, “...voor acht personen dek orang cuma nganga dong makan.” In English, it means '... for eight people, and then they only look at it, they eat' (Muysken, 2000).

Lastly, congruent lexicalization is a process where two languages share the same grammatical structure. However, the vocabulary used in the sentence or phrase is from two or more languages. It can be seen in this sentence, "Her grandma is a typical Familienmensch, where a German word is put in an English sentence because those two languages have similar grammatical structures (Cantone, 2007).

\subsection{Features of Code-Switching}

Muysken (2000) classifies the features of CS based on three types of CS. First, in insertion, there are five features related to insertion. Those are single constituents, nested a b a, content words, selected elements, and morphological integration.

Single constituent is how single words become the switched elements in CS phenomena. Usually, the inserted words are noun phrases because those are considered flexible to be inserted. The next is nested $\mathrm{a} \mathrm{b}$ a, which is a structure where the fragment 
before and after the insertion are related grammatically. The example of nested a $b$ a is in this sentence in Bolivian Quechua that receives some expressions from Spanish "Chay-ta las dos de la noche-ta chaya-mu-yku" that means 'there at two in the morning we arrive.' In the example, locative expression 'chay-ta' and 'chaya-mu-yku,' which is a verb, is in the same clause, so it is grammatically related.

Content words refer to nouns and adjectives inserted in a sentence or phrase where language switching occurs. Here is an example of insertion of Spanish words in an English sentence that uses content words, "Make it so the apple has más árboles." The words "más árboles' means 'more trees' that can be considered as content words.

After that, selected elements show how objects or complements are used as insertions in CS as seen in "Paga-wa-y uj qolqe duro-wan willa-sqa-yki-taj." The meaning is 'You had promised to pay him with hard cash.' Spanish insertions in the sentence receive Quechua case markings - $t a$ 'accusative' or -wan 'instrumental' (Muysken, 2000).

Lastly, morphological integration occurs when a grammar of one language becomes a grammatical framework, while another language that is morphologically the same or integrated, is switched into the core language. In this example, an English word is inserted into a Russian sentence, "požiloj mužčina s mašinoj, rabota deliveryman v landromate" (Sebba et al., 2012).

Second, in alternation, there are six features, namely several constituents, non-nested a $\mathrm{b}$ a, length and complexity, discourse particles and adverbs, tag-switching, and peripherality. Several constituents is when the language switching happens in some constituents. As an example, the French-Dutch sentence, "Je dois je dois glisser daan vinger hier" means 'I have to insert my finger here.'

Meanwhile, non-nested a b a happens when in a sentence of language $b$ uses several elements from another language (language a) before and after, but those elements are not related one to another. The example can be seen in "Bij mijn broer y a un ascenseur en alles" where Spanish words are switched after some words in Dutch, then are followed by other words in Dutch again.

Length and complexity show how alternation can be seen clearly when there are more words in a switched fragment. Here is a long fragment in French that continues the previous fragment in Dutch to make a full sentence, "Ze gaand at arrangeren van binnen voor appartementen te doen parce que c'est comment dirais-je c'est pas antique c'est classé.'

Discourse particles and adverbs are related to the use of discourse particles or adverbs as switching in CS phenomena. The example is "Pertang ze hadden gezeit dat ik die mocht hebben." Here, 'pertang' is a Malay adverb that is used in a Dutch sentence. Tag-switching occurs when tags and interjections are used in mixing two languages or more in one sentence. A French sentence with formulaic expression from English as, "Les autres pourraient [sic] parler français comme lui, ya know" is an example of tag-switching (Bullock \& Toribio, 2009). Last, peripherality is related to switching that happens at the periphery or not at the central of a sentence. For example, "Nous on parle français le flamand en de hele boel"' (Muysken, 2000).

Third, in congruent lexicalization, there are ten features that become the characteristics of CS phenomena. Linear and structural equivalence become the first feature, where the same material is switched in the same position. The example can be found in this Dutch and 


\section{Agatha Elma Febiyaska \& Priyatno Ardi}

Ottersum dialect sentence from (Muysken, 2000), "As wij nou zegge da we et anders wille, wa dan?"

Multi-constituent code-mixing shares the same syntactic structure between two languages and the language switching can be anywhere. In this sentence, more constituents are switched, "Voor gistere hebbe jullie 't ingedeeld wa."

Non-constituent mixing in congruent lexicalization occurs when the language switching only includes single words in the same shared structure. Non-nested a b a structures can happen here too, because elements from a language are possible not to have correlation with a single well-defined constituent. "Ja maar bij ouwe mensen komt dat gauwer tot stilstand als bij jonge mense wa," is a sentence that has no connection in grammar neither between the dialect fragments nor the standard variety fragment (Muysken, 2000).

Furthermore, function words are also used in congruent lexicalization. Function words refer to a switching feature that uses elements which do not have a general meaning or have no meaning at all, but simply a grammatical function (Velupillai, 2012). The example is "Sommige elastiekjes zin kapot," meaning 'some rubber bands are broken.' The word in bold means 'are,' which is a grammatical function in English.

Besides, selected elements may occur because there are large selection restrictions of some elements that are included, as seen in "Vertel over jou maar effe." There is also homophonous diamorphs or the same phonetics between two switched languages. For example, the Dutch word 'en' has the same meaning and pronunciation as 'and' in English (Ramat, 1987).

Additionally, morphological integration is also one of the congruent lexicalization features because morphosyntactic systems are alike as in the example "Mi hermano bought some ice cream." 'Mi hermano' means 'my brother,' which shows how those phrases have the same morphosyntactic system (Bullock \& Toribio, 2009).

Triggering in CS phenomena occurs when a word can trigger another word of the switched language. In this sentence, "Mijn moeder <knoje > d'ak te loat was," the word in the bracket triggers the continuance of the dialect.

Mixed collocations and idioms are the last feature. It is the appearance of collocation of idioms that are formed by using two languages in a sentence of CS. The example of this feature is, "Tom, Tom [geef] effe de thee 's [en]." Literally, it means 'Tom, Tom give just the tea once to' and the proper translation in English is 'Tom, Tom please pass the tea.' The two elements in the brackets have the same lexicalized combination or idiom from two different languages.

\section{RESEARCH METHODS}

This research employed document analysis. Document analysis, also known as content analysis, is an analysis of message characteristics, which is objective and systematic (Neuendorf, 2002). The object of this research was printed GoGirl! Magazines of March to May 2016 editions. GoGirl! Magazine is an Indonesian teenage magazine that mostly uses Bahasa Indonesia, but it also contains a lot of English words, phrases, and sentences. Those three editions were chosen based on two reasons. The first reason was that the three editions 
represented the sufficient data of CS to be analyzed for this research. Second, the chosen magazines were published in 2016, which had interesting topics and news for at least several months or even the whole year. They had interesting topics because the topics were related to readers' age range. The topics were also the newest trend or the up-to-date issues, such as newest gadgets, teenage psychological problems, and recommended places for eating or holiday.

To analyze the data, the researchers underwent four data analysis techniques proposed by Cresswell (2003). The first technique was organizing the data; the researchers broke down the data into smaller units, highlighted the CS found in the magazines, typed it into a list in a table. Secondly, the researchers examined the data set to understand them well as whole data. In this stage, the researchers read the data repeatedly to make sure that there were no mistakes in the data analysis. Thirdly, the researchers identified the general categories and classified the data based on the types and features of CS employed in three editions of GoGirl! Magazine.

\section{FINDINGS AND DISCUSSION}

\subsection{Types of Code Switching in GoGirl! Magazine}

Based on the findings, there were 1.355 cases of CS found in GoGirl! Magazine of March to May 2016 editions. The mostly used type of CS was alternation and the least used type was congruent lexicalization.

Table 1 Types of Code Switching Appear in GoGirl! Magazines

\begin{tabular}{ccc}
\hline $\begin{array}{c}\text { Types of } \\
\text { Code Switching }\end{array}$ & Occurrence & Percentage \\
\hline Alternation & 685 & $50.55 \%$ \\
\hline Insertion & 441 & $32.55 \%$ \\
\hline $\begin{array}{c}\text { Congruent } \\
\text { Lexicalization }\end{array}$ & 229 & $16.9 \%$ \\
\hline Total & 1.355 & $100 \%$ \\
\hline
\end{tabular}

Table 1 shows the occurrence of each type of CS in the magazines. Alternation was used in 685 sentences (50.55\%), insertion appeared 441 times (32.55\%), and congruent lexicalization was shown in 229 sentences (16.9\%).

The detailed discussion on each CS type found in GoGirl! Magazine of March to May 2016 editions is as follows.

\subsubsection{Alternation}

Alternation is a language shifting that usually happens in a sentence with maximal stretches. As a result, the switching can appear less, which means that in a sentence of language A using phrases or even a clause in language B (Bullock \& Toribio, 2009). The examples of alternation found in the magazines as follows. 
Agatha Elma Febiyaska \& Priyatno Ardi

(1) Bukannya underestimate, tapi karena otak kita masih dalam masa perkembangan, anak muda cenderung act on impulse tanpa terlalu mikirin resiko atau akibatnya. (April Edition, p. 59).

(2) Setelahnya aku ikut art meeting, di mana writers dan tim graphic design ngebahas soal konsep foto dan layout yang akan dipake di majalah. (May Edition, p. 38).

In the first example, an English word and an English phrase appeared in a sentence which mainly used Bahasa Indonesia. The appearance of several English words were considered as alternation that could be identified easily by looking at the appearance of several switching words. The use of English words may happen because the writers could not find appropriate terms in Bahasa Indonesia (Yusuf et al., 2018). Alternation type also occurs when grammar from two languages are compatible or at least equivalent (GardnerChloros, 2009). The example is in (3).

(3) 'Kita bisa ngecek menu yang tersedia di sana beserta harganya, foto-foto tempat dan menunya, and we can also read some reviews from the past visitors.'

The example shows that Indonesian and English grammar are used equivalently in a sentence. The sentence is understandable and acceptable. The writers chose to switch from Indonesian independent clause to English independent clause to give an emphasis on a certain point (Yusuf, Fata, \& Chyntia, 2018). Alternation became the mostly used type of CS in the magazine with $685(50.05 \%)$ occurrences.

\subsubsection{Insertion}

According to Gardner-Chloros (2009), insertion is a process of language shifting by putting a word in another language into a sentence. The example of the magazines can be seen as follows.

(4) Pada awalnya aku struggle karena nggak bisa nulis. (March Edition, p. 51).

(5) Nggak cuma temen seangkatan aja yang notice, tapi juga angkatan pacar atau bahkan satu sekolah. (May Edition, p. 42).

The examples in (4) and (5) are insertion since English words were used to replace the words that should have been written in Bahasa Indonesia. Martin-Anatias (2018a) argues that the phenomena of inserting English in Indonesian popular texts is to show a sense of modernity. There were 441 cases on insertion that occur in three editions of GoGirl! Magazine, namely 176 in March, 137 in April, and 128 in May.

\subsubsection{Congruent Lexicalization}

Congruent lexicalization is a unique mixture of alternation and insertion because the grammar used is that of the main language, but some words or phrases of other languages are inserted. The examples are as follows.

(6) For now, mereka ini wajib di-download buat maksimalin editing game dalam smartphone kita. (March Edition, p. 36). 
(7) Masker ini sheet-nya jauh lebih tebal dibanding mask sheet pada umumnya, dan essence-nya lebih banyak dan kental, nggak kayak essence lainnya. (April Edition, p. 124).

Two examples found in the magazines show how congruent lexicalization happened in a sentence. In (6), the sentence used Indonesian grammar, but there were English phrases and words inserted. An English word was even combined with the Indonesian prefix $d i$-. Furthermore, in (7), the Indonesian suffix -nya was combined with English words. Despite the insertion of English words, the grammar was still in Bahasa Indonesia. The writers probably used congruent lexicalization because they could not find the equivalent terms in Bahasa Indonesia (Yusuf et al., 2018) or wanted to show a sense of modernity through the use of English (Martin-Anatias, 2018a)

\subsection{Features of Code Switching in GoGirl! Magazine}

Muysken (2000) states that in each CS type, there are some features that may occur. First, alternation has six features, namely several constituents, non-nested a b a, length and complexity, discourse particles and adverbs, tag-switching, and peripherality. In alternation, the most common features found in GoGirl! Magazine of March to May 2016 editions included several constituents and non-nested a $\mathrm{b}$ a.

Second, there are five features in insertion, namely single constituent, nested a b a, content words, selected elements, and morphological integration. Three out of five features mostly used in the magazines were single constituent, nested a b a, and content words.

Third, ten features in congruent lexicalization are linear and structural equivalence, multi-constituent code-mixing, non-constituent mixing, non-nested a b a, function words, selected elements, homophonous diamorphs, morphological integration, triggering, and mixed collocation and idioms. There were two features that the magazines used frequently, namely linear and structural equivalence and non-nested a $\mathrm{b}$ a.

Table 2 Types and Features of Code Switching Found in GoGirl! Magazines

\begin{tabular}{clc}
\hline $\begin{array}{c}\text { Types and } \\
\text { Occurences }\end{array}$ & \multicolumn{1}{c}{ Features } & Findings \\
\hline $\begin{array}{c}\text { Alternation } \\
685\end{array}$ & Several Constituents & 685 \\
\cline { 2 - 3 } & Non-Nested a b a & 686 \\
\cline { 2 - 3 } & Length \& Complexity & 311 \\
\cline { 2 - 3 } & Discourse Particles \& Adverbs & 4 \\
\cline { 2 - 3 } & Tag-Switching & 3 \\
\cline { 2 - 3 } & Peripherality & 440 \\
\hline Insertion & Single Constituent & 440 \\
\cline { 2 - 3 } & Nested a b a & 411 \\
\cline { 2 - 3 } & Content Words & - \\
\cline { 2 - 3 } & Selected Elements & 4 \\
\hline
\end{tabular}

JELTL (Journal of English Language Teaching and Linguistics), 4(3), 2019 
Agatha Elma Febiyaska \& Priyatno Ardi

\begin{tabular}{clc}
\hline & Morphological Integration & - \\
\hline $\begin{array}{c}\text { Congruent } \\
\text { Lexicalization } \\
229\end{array}$ & Linear \& Structural Equivalence & 134 \\
\cline { 2 - 3 } & Multi-constituent Code-Mixing & 35 \\
\hline & Non-constituent Mixing & 9 \\
\hline Non-Nested a b a & 120 \\
\hline Function Words & - \\
\hline Selected Elements & - \\
\hline Homophonous Diamorphs & - \\
\hline & Morphological Integration & 28 \\
\hline & Triggering & - \\
\hline & Mixed Collocation \& Idioms & \\
\hline
\end{tabular}

\subsubsection{Several Constituents}

The occurrences of several constituents in the magazines were 685 . It was a feature that occurred in alternational CS, meaning that there were more than one constituent in the language shifting.

(8) Kalo ngerasa hunting sendirian bakalan garing, ajak temen-temen ikutan dengan bikin fun activity di small circle kita. (May Edition, p. 41).

In (8), the verb "hunting" and noun phrase "fun activity" and "small circle" were used in the Indonesian sentence, which was written in Indonesian grammar. Since there were five constituents as the switched words in a sentence, it was classified as several constituents.

\subsubsection{Non-nested a b a}

A case of CS is called non-nested a $\mathrm{b}$ a when the grammatical structures before and after the CS comes from different languages, but they are not related to another (Deuchar, 2005). There were 686 non-nested $\mathrm{a} \mathrm{b}$ a features in the magazines. The example of the occurrence of non-nested $\mathrm{a} b \mathrm{a}$ in the magazine is as follows.

(9) Trend may come and go, tapi ketika kita udah kuliah inilah saat yang pas banget buat nemuin style kita. (April Edition, p. 32).

The phrase "trend may come and go" was written in English, but it was followed by an Indonesian clause. It is clear that both languages have different grammatical structures, which were used in one sentence. Although the grammars around the switched words were different and not related, they still produced an understandable sentence so that this case was called non-nested a b a feature.

\subsubsection{Length and Complexity} follows.

This feature can easily show how a phrase or sentence uses CS. The example is as 
(10)This type isn't always introvert, tapi yang pasti mereka bener-bener perlakuin social media layaknya media satu arah lain kayak buku atau koran. (March Edition, p. 49).

In (10), there were seven English words. In addition, the CS appeared in a clause form, which was more complicated compared to a phrase. The appearance of the English words and the complexity of the word order was identified as alternation. Alternation happened 311 times in the magazines.

\subsubsection{Discourse Particles and Adverbs}

The occurrences of English discourse particles, such as oh, well, then, so, and or in a sentence that used CS showed how alternation happened. It can be clearly seen in (11).

(11)Well, karena melakukan pemotretan terkadang nggak semudah kelihatannya. (March Edition, p. 98).

\subsubsection{Peripherality}

CS can happen everywhere in a sentence, but if it happens at the beginning or end of the sentence, either at the left or right side, the feature is called peripherality. Peripherality was found three times in the magazines.

(12)Tapi support dari keluarga dan fans aku Alicious, bikin percaya diri buat bikin album dan hopefully dengan album ini orang bisa liat sisi lain aku. (March Edition, p. 16).

(13)Beberapa primer juga ngasih manfaat seperti menghidrasi kulit dan juga menutrisi kulit wajah, jadi efek yang kita dapetin ketika menggunakan primer bisa double. (May Edition, p. 118).

It can be seen from the two examples how the words 'support', 'primer', and 'double' were at the beginning or the end of the sentences. The words 'support' and 'primer' was at the left side, while 'double' was at the right side of the sentence.

\subsubsection{Single Constituent}

Single constituent is a condition where an English lexical item or constituent is inserted into a sentence that uses Indonesian grammar. The examples are as follows.

(14)Bukunya laris terjual sebanyak 15 ribu copy cuma dalam dua hari! (March Edition, p. 29).

(15)Di usianya yang terbilang muda, nggak sedikit achievement yang berhasil beliau raih saat ini. (April Edition, p. 52).

(16)Dan yang paling penting, menurutku consistency, jangan mudah merasa puas meskipun udah berhasil bikin satu lagu dan langsung meledak. (May Edition, p.131).

It can be seen in each example that an English word was simply inserted into a sentence as a CS. The example in (15) was a sentence with Indonesian grammar, but instead of using the Indonesian word 'pencapaian,' it used an English word 'achievement' and it was still wellunderstood. There were 440 single constituent features used in the magazines. 
Agatha Elma Febiyaska \& Priyatno Ardi

\subsubsection{Nested a b a}

Nested a b a occurs when a switch is put between other words from the main language. This feature happened 440 times in the magazines. In this case, an English word or phrase was written after some Indonesian words, followed by other words in Bahasa Indonesia. This is considered as nested $\mathrm{a} b$ a.

(17)Tapi, bukan berarti gadget ini nggak bakal jadi tren di tahun ini. (March Edition, p. 32).

(18)Artinya, mungkin aja perasaan self doubt ini akan terus ada, seiring dengan berkembangnya pengalaman kita. (April, p. 41).

(19)Nggak hanya arsitekturnya yang artsy, tapi koleksi bukunya juga nggak kalah nyeni. (May Edition, p. 70).

So, ' $\mathrm{a} \mathrm{b}$ a' in 'nested $\mathrm{a} b$ a' means that $a$ is Indonesian words in its grammar, $b$ is English words, then $a$ is Indonesian again. In (19), the first four words were in Indonesian, but it was continued with an English adjective and followed by seven Indonesian words. It can be seen that the main language was Bahasa Indonesia and when a word or phrase in English was put between the words of the main language, it became a nested a $b$ a feature.

\subsubsection{Content Words}

Content words include verbs, nouns, and adjectives (Muysken, 2000) that function as switching in a sentence as portrayed below.

(20)Good background bisa nonjolin objek foto, dan nggak mendistraksi fokusnya. (March Edition, p. 35).

The example shows how a noun and adjective that became a noun phrase was inserted into a sentence with Indonesian grammar. There were 411 cases of content words used as switching in the magazines.

\subsubsection{Linear and Structural Equivalence}

The linear and structural equivalence feature occurs when the switched items take place at the equal position in a clause of the main language. The magazines used 134 linear and structural equivalence features. The example of this feature is as follows.

(21)Nggak heran ngeliat segitu gede antusias para fans-nya, karena musik Alessia kedengeran jauh lebih rich ketika live. (April Edition, p. 24).

In the example, the English words 'fans', 'rich', and 'live' were placed in the same place as if they were written in Bahasa Indonesia. The placement followed Indonesian grammar because the position of the three words in English was the same as if they were written in Bahasa Indonesia. Therefore, those English words were linear with Indonesian grammar. 


\subsubsection{Multi-Constituent Code-Mixing}

Two syntactic structures of the two languages are the same and the switching happens anywhere; it becomes a feature of CS that is multi-constituent code-mixing. In the magazines, there were 35 cases of this feature. One of the examples is as follows.

(22)Play with layer and texture, terutama buat flatlays photo. (March Edition, p. 35).

(23)Kalo kita lagi ada masalah, we can talk to him tanpa ada judgement and with

a lot of patient - abis itu dia bakalan nenangin kita dengan caranya yang magically bener-bener masuk ke logika kita. (April Edition, p. 61).

The two examples show how multi-constituent code-mixing occurred in two ways, namely the use of Indonesian words in a sentence using English grammar, as shown in (22) or the other way around, as seen in (23).

\subsubsection{Non-Constituent Mixing}

Different from multi-constituent code-mixing, the non-constituent mixing feature only allows one word as the switching in the same structure shared by the two languages involved. The example is as follows.

(24)A good friend of mine mengatakan, "Treat people the way you want to be treated, not by how they treated you." (April Edition, p.108).

The example presents how the word 'mengatakan' was the only Indonesian word inserted into a sentence that used English grammar. There were 9 sentences using nonconstituent mixing in the magazines.

\subsubsection{Triggering}

A CS case has triggering feature if a sentence of language A uses one word from language B, which triggers an appearance of another word in language B afterwards (Deuchar, 2005). The example of triggering in the magazines is as follows.

(25)Lewat Airbnb, kita bisa nyari dan booking rumah, vila atau apartemen di seluruh dunia secara online, at any price point. (March Edition, p. 39).

In the example, the English word 'online' is an adjective. The word triggered the other English words, namely 'at any price point' that explained more about the word 'online.'

\section{CONCLUSION}

This article reports on a study investigating the types and features of code switching in GoGirl! Magazine of March to May 2016 editions. Based on the findings, there were three types, namely alternation, insertion, and congruent lexicalization. Alternation was used in 685 cases $(50.55 \%)$ from the total 1.355 code-switching that appeared in the three editions of GoGirl! Magazine. Insertion and congruent lexicalization happened in 441 and 229 cases. Therefore, it can be concluded that alternation was the most frequently used type in the magazines, while congruent lexicalization was the least. Alternation type was used frequently because it gave more flexibility in switching languages. As a result, the writers of the magazine may use several English words or even phrases and clauses in a sentence. Furthermore, the appearance of alternation type reflected writers' good English. Congruent lexicalization became the least used type because grammar mixing, such as "fans-nya", seemed to be not flexible, even though it was still understandable. 
Agatha Elma Febiyaska \& Priyatno Ardi

The features of CS found in GoGirl! Magazine of March to May 2016 editions were twelve features. The twelve features included several constituents, non-nested a $b$ a, length and complexity, discourse particles and adverbs, peripherality, single constituent, nested a b a, content words, linear and structural equivalence, multi-constituent code-mixing, nonconstituent mixing, and triggering. Among 18 features, six features were not found in the magazines, namely tag-switching, selected elements, morphological integration, function words, homophonous diamorphs, and mixed collocation and idioms. The most frequently used feature was non-nested a b a with 686 occurrences.

\section{REFERENCES}

Adityanto, K. (2012). Code Switching in Kompas and Republika Newspapers. Sanata Dharma University.

Altarriba, J., \& Basnight-Brown, M. D. (2009). Empirical Approaches to the Study of CodeSwitching in Sentential Contexts. In Multidisciplinary Approaches to Code Switching. Amsterdam: John Benjamins Publishing Company.

Auer, P. (1998). Bilingual Conversation Revisited. In Code-Switching in Conversation. London: Routledge.

Bullock, B. E., \& Toribio, A. J. (2009). The Cambridge Handbook of Linguistic CodeSwitching. New York: Cambridge University Press.

Cantone, K. F. (2007). Code-Switching in Bilingual Children. Dordrecht: Springer.

Cresswell, J. W. (2003). Research Design, Qualitative, Quantitative, and Mixed Method Approach (2nd ed.). California: Sage Publications.

Das, A., \& Gambäck, B. (2013). Code-Mixing in Social Media Text. TAL Journal, 54, 4164.

Deuchar, M. (2005). Minority Language Survival: Code-Mixing in Welsh. Proceedings of the 4th International Symposium on Bilingualism. Somerville: Cascadilla Press.

Gardner-Chloros, P. (2009). Code-Switching. New York: Cambridge University Press.

Martin-Anatias, N. (2018a). Bahasa Gado-Gado: English in Indonesian Popular Texts. Word Englishes, 37(2), 340-355.

Martin-Anatias, N. (2018b). Language Selection in the Indonesian Novel: Bahasa GadoGado in Expressions of Love. South East Asia Research, 26(4), 347-366.

Martin-Anatias, N. (2019). Code-Switching or Bahasa Gado-Gado in Discussion of Homosexuality in Indonesian Films. Journal of Homosexuality, 1-23.

McCormick, K. M. (1994). Code-Switching and Mixing. Oxford: Pergamon Press.

Muysken, P. (2000). Bilingual Speech: A Typology of Code-Mixing. Cambridge: Cambridge University Press.

Neuendorf, K. A. (2002). Content Analysis Guide Book. California: Sage Publication Inc. Ramat, P. (1987). Linguistic Typology. Berlin: Mouton de Gruyter.

Rusli, W. N., Shaari, A. H., Zainuddin, S. Z., Shi, N. L., \& Amin, A. S. (2018). Intra and Intersentential Code-switching Phenomena in Modern Malay Songs. 3L: The Southeast Asian Journal of English Language Studies, 24(3), 184-205. 
Sebba, M., Mahootian, S., \& Jonsson, C. (2012). Language Mixing and Code-Switching in Writing. New York: Routledge.

Velupillai, V. (2012). An Introduction to Linguistic Typology. Amsterdam: John Benjamins Publishing Company.

Wardhaugh, R. (1992). An Introduction to Sociolinguistics (2nd ed.). Oxford: Blackwell Publishing.

Yusuf, Y. Q., Fata, I. A., \& Chyntia. (2018). Types of Indonesian-English Code-Switching Employed in a Novel. Kasetsart Journal of Social Sciences, 1-6.

Zhiganova, A. V. (2016). The Study of the Perception of Code-Switching to English in German Advertising. Procedia - Social and Behavioral Sciences, 236, 225-229. 